\title{
Cerebral vascular anomalies in a large Italian family with late-onset glycogenosis II
}

\author{
F Cipullo*, S Sampaolo, O Farina, M Simonetti, M Cirillo, G Di lorio \\ From Proceedings of the 6th European Symposium: Steps Forward in Pompe Disease \\ Berlin, Germany. 23-24 November 2012
}

\section{Introduction}

Basilar artery dolichoectasia, ectasia of internal carotids and intracranial aneurysm have been described in lateonset glycogenosis II (GSD II). Incidence of these anomalies and their relationship to the genotype are unknown. Also, because studying cerebral vessels is not recommended for diagnosis of late-onset GSDII, the frequency of these anomalies may be underestimated. Therefore, we investigated the occurrence of vascular anomalies in eight siblings (4M, 4F) of an Italian family affected by late-onset GSDII due to a compound mutation (c.118C $>\mathrm{T}$ in exon 2 and c.2647-7G $>\mathrm{A}$ in intron $18)$ of the acid $\alpha$-glucosidase (GAA) gene (17q21-23).

\section{Results}

The clinical picture in these siblings is typical of late-onset GSDII: Patients never complained of symptoms of cerebro-vascular disease and none had cardiac involvement. Blood pressure and blood glucose were normal. Brain Magnetic Resonance Angiography (MRA; Angio-RM TOF 3D axial Siemens Synphony 1.5 T) was performed in 7 (4M, 3F) out of 8 patients (one female carried a paramagnetic prosthesis), and in 10 controls. Vessel total square diameter was measured at the apex and middle third of the basilar artery and at the middle portion of both right and left internal carotid artery. Blind measurements were carried out by three investigators. Basilar artery dolichoectasia $(0.06 \%$ in the general population) was found in $3 \mathrm{M}$ and $2 \mathrm{~F}$, and a slight dilatation of internal carotids compared to controls was found in all patients.

\section{Conclusion}

These data confirm that anomalies of main cerebral vessels are relatively frequent in late-onset GSDII patients. The role of genotype in determining these anomalies is

Dipartimento di Scienze Mediche, Chirurgiche, Neurologiche, Metaboliche e dell'Invecchiamento - Seconda Università di Napoli, Naples, Italy uncertain because studies on informative families are rare. Particularly intriguing is the relation of these vascular anomalies with the risk of stroke in these patients. Even though all have ventilatory insufficiency with reduced blood oxygen saturation, nocturnal apnea, and impaired glycogen metabolism, a minority suffer TIA or stroke. Therefore, an imaging study of the cerebral circulation is recommended in all patients with late-onset GSDII. In those with anomalies, further research is needed to evaluate cerebral metabolism and to search for specific vascular risk factors.

Published: 29 May 2013

doi:10.1186/1471-2474-14-S2-P10

Cite this article as: Cipullo et al:: Cerebral vascular anomalies in a large Italian family with late-onset glycogenosis II. BMC Musculoskeletal Disorders 2013 14(Suppl 2):P10.

Submit your next manuscript to BioMed Central and take full advantage of:

- Convenient online submission

- Thorough peer review

- No space constraints or color figure charges

- Immediate publication on acceptance

- Inclusion in PubMed, CAS, Scopus and Google Scholar

- Research which is freely available for redistribution
C Biomed Central

C 2013 Cipullo et al; licensee BioMed Central Ltd. This is an Open Access article distributed under the terms of the Creative Commons Attribution License (http://creativecommons.org/licenses/by/2.0), which permits unrestricted use, distribution, and reproduction in any medium, provided the original work is properly cited. 